\title{
PENGARUH BREASTCARE DAN AIR SEDUHAN DAUN KELOR TERHADAP PRODUKSI ASI
}

Galih Setia Adi, Prodi Sarjana Keperawatan, Stikes Kusuma Husada Surakarta

e-mail: galihkh88@gmail.com

Saelan, Prodi Sarjana Keperawatan, Stikes Kusuma Husada Surakarta

e-mail: Saelanelan@gmail.com

Rahajeng Putriningrum, Prodi Sarjana Keperawatan, Stikes Kusuma Husada Surakarta

e-mail: rahajaengputriningrum@yahoo.com

Aria Nurahman H.K, Prodi Sarjana Keperawatan, Stikes Kusuma Husada Surakarta

e-mail: Ariahendra25@yahoo.com

\section{ABSTRACT}

Pemberian ASI ekslusif merupakan pemberian asi sejak bayi baru dilahirkan, dan disusui selama 24 jam tanpa pemberian makanan dan minuman apapun selain ASI. Saat ini cakupan pemberian ASI ekslusif Pada bayi umur 0-6 bulan, di Indonesia terdapat 19 provinsi yang cakupannya berada di atas rata-rata angka nasional (54,3\%). Angka tersebut merupakan angka yang sudah bagus karena sudah berada di atas angka nasional. Namun angka tersebut belum bisa mencapai $100 \%$, maka dari itu diperlukan cara untuk dapat meningkatkan angka cakupan pemberian ASI pada bayi 0-6 bulan.

Data tersebut memberikan bukti bahwa banyak ibu yang tidak memberikan ASInya. Para ibu tidak memberikan ASInya antara lain ASI tidak keluar di awal kelahiran bayi, keluarga yang tidak mensupport ibu dalam pemberian ASI, karena ibu bekerja sehingga sulit untuk menyusui. Tujuan untuk mengetahui pengaruh terapi hypnopunturbreastfeeding dan air seduhan daun kelor terhadap produksi asi di kabupaten sukoharjo.

Desain penelitian ini adalah pre and post test without control group jumlah responden adalah 28 responden. Analisis bivariat selanjutnya menggunakan uji Paired sample $t$-test.

Hasil penelitian terdapat perbedaan antara sebelum dan sesudah diberikan terapi brest care dan air seduhan daun kelor hal tersebut tampak dari nilai sig 0.000 lebih kecil dari 0.005 . sehingga dapat disimpulkan bahwa terapat pengaruh terapi brestcare dan air seduhan daun kelor terhadap produksi asi di kabupaten sukoharjo.

Keywords: Asi,Moringa leaves steeping water,daun kelor, seduhan

\section{PENDAHULUAN}

ASI merupakan makanan pokok bayi yang sangat baik, karena di dalam ASI terdapat kandungan zat gizi yang dapat mencegah bayi dari penyakit infeksi : diare, otitis media acuta, alergi dan saluran pernafasan akut bagian bawah. Kandungan gizi ASI memberikan proteksi pada kekebalan tubuh bayi, sehingga bayi dapat tumbuh dan berkembang dengan sangat baik. Menurut WHO ( World Health Organitation) menyatakan bahwa sebaiknya bayi hanya diberikan ASI sampai usia paling sedikit 6 bulan, dan setelah itu diberikan makanan tambahan dilanjutkan dengan tetapa memberikan Air Susu Ibu selama dua tahun. Betapa pentingnya pemberian ASI ini pada bayi-bayi, khususnya bayi Indonesia yang mana sebagai calon generasi penerus bangsa yang kelak nantinya di tangan mereka keberhasilan bangsa. Pemberian Asi selama paling sedikit enam bulan disebut sebagai pemberian ASI ekslusif. Menurut Riskesdas tahun 2010 pemberian ASI ekslusif merupakan pemberian asi sejak bayi baru dilahirkan, dan disusui selama 24 jam tanpa pemberian makanan dan minuman apapun selain ASI. Saat ini cakupan pemberian ASI ekslusif Pada bayi umur 0-6 bulan, di Indonesia terdapat 19 provinsi yang cakupannya berada di atas rata-rata angka nasional (54,3\%). Adapun di Jawa Tengah cakupan pemberian ASI Ekslusif mencapai angaka 58,4\% pada tahun 2013 (Infodatin, 2013). Angka tersebut merupakan angka yang sudah bagus karena sudah berada di atas angka nasional. Namun angka tersebut belum bisa mencapai $100 \%$, maka dari itu diperlukan cara untuk dapat meningkatkan angka cakupan pemberian ASI Ekslusif pada bayi 06 bulan. (Kemenkes RI,2010).

Studi pendahuluan yang dilakukan di lapangan banyak berbagai alasan yang menyebabkan para ibu tidak memberikan ASInya antara lain ASI tidak keluar di awal kelahiran bayi, keluarga yang tidak 
mensupport ibu dalam pemberian ASI, karena ibu bekerja sehingga sulit untuk menyusui. Alasan-alasan di atas sebenarnya dapat diantisipasi dengan berbagai cara dan metode. Salah satu metode yang ada yaitu Breastcare seduhan air daun kelor.

Berdasarkan penelitian Zakaria dkk (2015) pemberian ekstrak daun kelor berpotensi meningkatkan kadar $\mathrm{Hb}$ sehingga menurunkan anemia ibu, walaupun kadar besi susu tidak meningkat secara signifikan. Sedangkan penelitian Sulistyawati (2017) tidak ada efek signifikan pada berat badan bayi. Dengan demikian, dapat disarankan agar moringa oleifera dapat digunakan sebagai pengobatan alternatif untuk meningkatkan produksi ASI dan hormon prolaktin. Produksi ASI tidak di tentukan dari berat bayi tetapi lama Maka dari itu perlu dilakukan penelitian terhadap "Pengaruh Air Seduhan Daun Kelor Terhadap Produksi ASI".

\section{RUMUSAN MASALAH}

Sesuai permasalah tersebut di atas dapat di ambil rumusan masalah sebagai berikut :Adakah pengaruh Breastcare dan Air Seduhan Daun Kelor Terhadap Produksi ASI?

\section{TUJUAN PENELITIAN}

Adapun tujuan umum dari penelitian ini yaitu untuk mencari pengaruh air seduhan daun kelor terhadap produksi ASI.

\section{LITERATUR DAN PENGEMBANGAN HIPOTESIS}

A. ASI

ASI adalah makanan terbaik bagi bayi, oleh karena itu diperlukan upaya komprehensif untuk meningkatkan pemberian ASI eksklusif, yang melibatkan semua unsur mulai dari kesadaran ibu, peran keluarga, masyarakat serta pelayanan kesehatan. Menurut penelitian mustofa \& prabandari (2010) Bayi akan mendapatkan asupan yang cukup nutrisi dan zat esensial seperti zat kekebalan tubuh sehingga ia bisa tumbuh normal baik secara fisik maupun psikis. Untuk lbu yang memberi ASI kepada bayinya akan mendapat manfaat positif bagi kesehatan paska melahirkan. Selain itu adanya kolostrum dalam ASI berfungsi sebagai pelindung yang kaya zat anti infeksi, berprotein tinggi dan pencahar yang ideal untuk membersihkan zat yang tidak terpakai dari usus bayi yang baru lahir dan mempersiapkan saluran pencernaan makanan bayi bagi makanan yang akan datang (Fikawati, 2010). Agar bayi optimal mendapatkan ASI ma diperlukan beberapa kiat menuju keberhasilan antara lain usahakan memberi minum dalam suasana yang santai bagi ibu dan bayi. Buatlah kondisi ibu senyaman mungkin. Selama beberapa minggu pertama, bayi perlu diberi ASI setiap 2,5 - 3 jam sekali. Penentu kelancaran ASI perlu posisi menyusui juga sangat penting mempengaruhi keberhasilan dalam menyusui dan dengan posisi menyusui yang benar maka memberi rasa nyaman kepada ibu dan bayinya.Hasil penelitian Contesa (2012) posisi menyusui mempengaruhi puting susu,bila ibu cara menyusui salah mengakibatkan lecet.

\section{B. Daun Kelor}

Daun tanaman kelor memiliki karakteristik bersirip tak sempurna, kecil, berbentuk telur, sebesar ujung jari. Helaian anak daun memiliki warna hijau sampai hijau kecoklatan, bentuk bundar telur atau bundar telur terbalik, panjang 1-3 cm, lebar $4 \mathrm{~mm}$ sampai $1 \mathrm{~cm}$, ujung daun tumpul, pangkal daun membulat, tepi daun rata. Kulit akar berasa dan berbau tajam dan pedas, dari dalam berwarna kuning pucat, bergaris halus, tetapi terang dan melintang. Tidak keras, bentuk tidak beraturan, permukaan luar kulit agak licin, permukaan dalam agak berserabut, bagian kayu warna cokelat muda, atau krem berserabut, sebagian besar terpisah. Hasil penelitian Sulistiawati (2017) efek moringa oleifera pada ibu Prolaktin dan durasi tidur bayi. Namun, tidak ada efek signifikan berat bayi

Daun kelor merupakan salah satu bagian dari tanaman kelor yang telah banyak diteliti kandungan gizi dan kegunaannya. Daun kelor sangat kaya akan nutrisi, diantaranya kalsium, besi, protein, vitamin A, vitamin B dan vitamin C. Daun kelor mengandung zat besi lebih tinggi daripada sayuran lainnya yaitu sebesar $17,2 \mathrm{mg} / 100 \mathrm{~g}$ (Yameogo et al. 2011). Daun kelor terlebih dahulu diekstraksi dengan menggunakan pelarut etanol $96 \%$, kemudian dilakukan uji fitokimia untuk mendeteksi adanya senyawa aktif alkaloid, flavonoid, saponin, fenolat, triterpenoida / steroida, dan tannin (Putra,2016). Hasil penelitian Kristina (2014) daun kelor mengandung fitosterol yang dapat meningkatkan produksi ASI bagi wanita yang sedang menyusui.Daun kelor mengandung $\mathrm{Fe}$ $5,49 \mathrm{mg} / 100 \mathrm{~g}$ dan fitosterol yakni sitosterol $1,15 \% / 100 \mathrm{~g}$ dan stigmasterol $1,52 \% / 100 \mathrm{~g}$ yang merangsang produksi ASI 


\section{Bahan Dan Cara membuat air seduhan} daun kelor

Bahan : Tiga tangkai daun kelor, Air matang $250 \mathrm{ml}$, Daun salam 1 buah, Bawang merah $1 / 2$ suing, Bawang putih $1 / 2$ suing, Garam $1 / 4$ sendok teh, Gula merah $1 / 2$ bagian

Cara mengolah : Ambillah satu sampai tiga tangkai daun kelor, Cuci bersih daun kelor lalu bersihkan bersih, Masukkan air kurang lebih dua gelas air tunggulah mendidih lantas masukkan daun kelor, Tambahkan 1 lembar daun salam, irisan bawang merah $1 / 2$ siung serta bawang putih $1 / 2$ siung, garam $1 / 4$ sendok teh serta dapat pula di tambah sedikit gula merah $1 / 2$ bagian, Cukup rebus kurang lebih 30 menit. (Purwanto,2015)

\section{METODE PENELITIAN}

Penelitian ini dilakukan di Bidan Praktek Swasta Fitri Handayani di Kabupaten Sukoharjo selama 4 bulan dikarenakan target waktu penelitian tidak mencukupi. Desain penelitian ini adalah pre and post test without control group. Responden pada intervensi dengan kriteria bersedia menjadi responden, usia produktif, mengalami masalah produksi asi tanpa mengalami indikasi penyakit tertentu, mengalami gangguan hormonal.

\section{JALANNYA PENELITIAN}

Penelitian ini dilakukan di Bidan Praktik Swasta Fitri Handayani Sukoharjo, sampel yang digunakan sejumlah 28 responden. sampel diberikan perlakuan brest care dan air seduhan daun kelor. Analisis bivariat selanjutnya menggunakan uji Paired sample ttest. Alat yang digunakan jarum akupuntur, air hangat, washlap, air seduhan daun kelor, alat pompa asi dan gelas ukur.

\section{HASIL PENELITIAN}

Analisis univariat pada penelitian ini menjelasakan karateristik respoden meliputi usia, pekerjaan, produksi asi sebelum perlakuan dan setelah perlakuan,

Tabel 1 Hasil Analisis Univariat Karakteristik Responden berdasarkan Usia

\begin{tabular}{|c|c|c|c|c|}
\hline Variabel & Min & Max & Mean & Median \\
\hline Usia & 17 & 38 & 29.9 & 5.6 \\
\hline
\end{tabular}

tahun, usia tersebut adalah usia yang aman pada reproduksi. Hal tersebut sesuai menurut Arini (2012) bahawa dalam kurun waktu reproduksi sehat dikenal usia aman untuk kehamilan, persalinan, dan menyusui adalah 20-35 tahun.
Tabel 2 hasil analisis bivariat pre dan post perlakuan Breascare dan airseduhan daun kelor

\begin{tabular}{cccc}
\hline Variabel & $\mathrm{N}$ & Corelation & Sig \\
\hline ASI & 28 & 0.746 & 0.000 \\
\hline
\end{tabular}

Bedasarkan tabel 2 terdapat perbedaan antara sebelum dan sesudah di berikan terapi brest care dan air seduhan daun kelor hal tersebut tampak dari nilai sig 0.000 lebih kecil dari 0.005. Menurut teori Tujuan Perawatan Payudara yaitu meningkatkan produksi ASI dengan merangsang kelenjar-kelenjar air susu melalui pemijatan, mencegah bendungan ASI/ pembengkakan payudara, melenturkan dan menguatkan putting, mengetahui secara dini kelainan puting susu dan melakukan usaha untuk mengatasi (Hadi,2008). Daun kelor yang mengandung antioksidan non-enzimatik seperti vitamin A (beta carotene), vitamin C dan vitamin $E$ yang dapat mengurangi kerusakan DNA17 serta senyawa fitosterol. Hal ini sesuai hasil studi Titi Mutiara (2011) yang melaporkan bahwa daun kelor mengandung senyawa fitosterol diantaranya kampesterol, stigmasterol, dan $\beta$-sitosterol yang bersifat laktagogum yang dapat meningkatkan produksi ASI. Hasil penelitiannya menunjukkan pemberian daun kelor dapat meningkatkan produksi air susu secara nyata seiring dengan peningkatan konsentarsi yang diberikan. Studi Yang dan Chang melaporkan bahwa daya cerna daun kelor yang telah diolah (dimasak dengan pemanasan) akan memiliki nilai daya cerna yang lebih tinggi dibandingkan dalam bentuk mentahnya, tetapi demikian Fahey menyebutkan bahwa kelor mengandung protein yang sangat mudah dicerna. (Wijnhoven,2009) bahwa asupan vitamin C ibu menyusui dari ekstrak daun kelor dapat berkontribusi dalam mencegah penurunan kadar vitamin C dalam ASI, karena sifat kimiawi vitamin $C$ yang berasal dari ekstrak daun kelor bioavailibilitas relatif baik larut dalam air, sehigga muda diabsorbsi. Hasil studi Hoppu et al. menyatakan bahwa konsentrasi dari vitamin $\mathrm{C}$ yang lebih tinggi dalam ASI berhubungan dengan penurunan risiko atopi pada bayi. (Antonakou,2011) hypnobreastfeeding mampu menghadirkan rasa santai, nyaman dan tenang selama menyusui dengan demikian maka seluruh system di dalam tubuh Anda akan berjalan jauh lebih sempurna sehingga proses menyusui-pun menjadi proses yang penuh arti dan menyenangkan baik bagi anda maupun bagi bayi anda. Bahkan hypnobreastfeeding 
mampu membantu ibu yang mengalami kesulitan saat menyusui juga dapat membuat ibu mampu untuk relaktasi. Sugesti dengarkan suara bayi, perhatikan dengkuran nafasnya. Maka akan terjadi baby bonding atau rasa sayang yang akan memicu hormon endorfin (hormon yang membuat ketenangan) sehingga tubuh pun lebih rileks. Jika sudah terbangun niat positif dari si ibu, maka pikiran akan semakin tenang, seluruh sel akan semakin sehat, dan produksi ASI cukup untuk kebutuhan bayi sampai usia 6 bulan. Sebenarnya bayi bisa disusui eksklusif hingga dua tahun. Sebab otak bayi mengalami perkembangan paling pesat di usia tersebut.

Akupuntur memiliki prinsip yang sama dengan akupresur. Perbedaan terletak pada alat yang digunakan. Akupuntur menggunakan jarum sedangkan akupresur menggunakan jari (Fengge, 2012). Setelah dilakukan akupresur pada kelompok intervensi, responden pada kelompok kontrol tingkat kecukupan ASI setelah dilakukan akupresur pada kelompok intervensi tidak mengalami perubahan yg signifikan.Penelitian ini juga menunjukkan bahwa kecukupan ASI meningkat dari 35\% menjadi $82 \%$ setelah diberikannya tindakan akupresur. Hal ini membuktikan bahwa terapi akupuntur pada titik REN 17,SJ 1,G27,H 14 dan P1.Ren 17 Shan Zhong terletak : Setinggi sela iga 4 , perpotongan gari meridian dan garis penghubung kedua putting susu.Menurunkan Qi yang naik,meredakan rasa penuh di dada,menenangkan pikiran.SJ 1 Guanchong di pangkal bawah jari manis mempunyai indikasi mejaga keseimbangan hormon prolaktin.Meridian G27 Shufu terletak di celah os klavikula pada iga ke 1.letak 2 cun lateral meridian ren/Xuanji(CV-21)mempunyai fungsi sebagai mengurangi rasa nyeri selama menyusui.Meridian H14 Ximen terletak pada garis lateral dada II,di bawah putting sela iga VI lateral dari meridian CV 4 cun indikasi nyeri dada.Meridian P1 Chong Fu terletak pada garis lateral dada III,setinggi sela iga 1 ,indikasi merangsang pada puting susu yang menyebabkan dilepaskannya oksitosin. Refleks ini dapat ditekan oleh pusat yang lebih tinggi di otak, yang menyebabkan stres dan cemas untuk mempengaruhi refleks "mengeluarkan". Terapi akupunktur dapat ditujukan pada relaksasi kuat juga menyediakan "tonik" untuk membangunibu, dan meningkatkan aliran energi atau "Qi" ke payudara. Telah diketahui bahwa akupunktur memiliki pengaruh yang kuat terhadap kadar hormon, dan tidak ada petunjuk mengenai pengaruhnya terhadap pusat yang lebih tinggi, sehingga beralasan untuk membuat spekulasi bahwa keberhasilannya dalam memulai laktasi dikarenakan oleh peningkatan kadar oksitosin dan prolaktin.

Kelor mengandung 18 asam amino, yaitu 8 jenis asam amino esensial dan 10 jenis asam amino non esensial. Asam amino esensial meliputi isoleusin, leucine, lisin, metionin, phenylalaine, treonin, tryptophan, valin. Asam amino nonesensial meliputi Alanin, Arginine, Asam Aspartat, Sistin, Asam Glutamat, Glycine, Histidin, Serine, Proline, Tryrosine. Kandungan asam amino kelor lebih banyak jika dibandingkan dengan asam amino telur. (Fuglie,2001). Daunnya yang kaya akan nutrisi merupakan sumber beta karoten, vitamin $\mathrm{C}$, besi, dan potassium. HasiJ analisis kandungan $\mathrm{Fe}$ dalam daun kelor di Balai Penelitian Tanaman Rempah dan Obat pada tabun 2014 menunjukkan hasil yang eukup baik, yaitu dari $\mathrm{J} \mathrm{Kg}$ simplisia dapat menghasilkan kandungan besi sebanyak 54,92 mg (Balittro, 2014). Kandungan besi dalam daun kelor memberikan manfaat untuk meng- atasi anemia baik pada anak-anak maupun ibu hamil dan menyusui. Cara lain daun kelor dapat dibuat tepung lalu dijadikan bubur untuk dikonsumsi. Umumnya masyarakat yang rajin mengkonsumsi kelor lebih berenergi dan lebih sehat karena tanaman kelor dapat me- menuhi kekurangan gizi dalam tubuh. Djajanti (2012) pada penelitian nya di dapatkan hasil bahwa Rebusan Daun Kelor pada konsentrasi 10\%, $20 \%$, dan $40 \%$ dapat meningkatkan produksi ASI pada mencit. Rebusan Daun Kelor dengan konsentrasi $40 \%$ menunjukkan efek yang optimal.

\section{Kesimpulan}

Terdapat perbedaan produksi ASI antara sebelum dan sesudah diberikan terapi brest care dan air seduhan daun kelor hal tersebut tampak dari nilai sig 0.000 lebih kecil dari 0.005 .

\section{Saran}

1. Bagi peneliti

Melanjutkan penelitian selanjutnya dan mengaplikasikannya sampai pengabdian masyarakat.

2. Bagi responden

Menjaga kesehatan dalam mengobati dengan cara alternatif sehingga produksi ASI tidak mengalami gangguan. 


\section{REFERENSI}

Armini.Hypnobreastfeeding awali suksesnya ASI Eklusif. Dosen Jurusan Kebidanan Politeknik Kesehatan Denpasar . 2016

Baharuddin.Pengaruh Akupuntur Payudara Terhadap Intensitas lbu Menyusui.Skripsi.Surabaya.Fakultas IImu Kedokteran Universitas Airlangga. 2009

Contesa,L. Pelaksanaan Posisi Menyusui Yang Benar Sebagai Upaya Mencegah Terjadi Putting Susu Lecet Di Rumah Bersalin Citra.Volume 8.No.3.Palembang.Jurnal Kesehatan Bina Husada. .2012

Kemenkes RI. 2010. Survey Statistik Angka Kematian lbu Di Indonesia.Edisi 1.Jakarta.Kementerian Republik Indonesia

Kirsch \& Irving, 2011. The altered states of hypnosis. Social Research; Fall 2001; 68, 3; ProQuest Sociology

Kiswojo, H.2014.Akupuntur Medik.Edisi 1.Jakarta. Penerbit Akupunktur Indonesia

Kusmiyati.dkk. 2014. Pengaruh Hypnobreastfeeding Terhadap kecemasan dan Waktu pengeluaran Air susu lbu pada lbu Post Partum Primipara di Yogyakarta. Jurnal Teknologi Kesehatan, vol. 12, No 2, November 2014

Kristina Nova N\& Siti Fatimah Syahid.2014.Pemanfaatan Tanaman Kelor (Moringa Oleifera) Untuk Meningkatkan Produksi Air Susu Ibu.Journal Warta Penelitian dan pengembangan tanaman industry.Volume 20 Nomor 3.Desember 2014

Kusuma,AK. 2008.Teori Dan Praktik Akupuntur.Jakarta:PT Gramedia

Larkin\&Marilynn.2011. Hypnosis makes headway in the clinic. The Lancet 358. (Dec 2001,01) ; 1917

Mann,RB \& Zhang.2014. Improvement in Lactation with Traditional Chinese Medicine and Western Herbal Medicine: A Case Study. Number 105. June 2014.Journal of Chinese Medicine

Mustofa \& Prabandari.2010.Pemberian ASI Ekslusif Dan Problematika Ibu Menyusui. Jurnal Studi Gender \& Anak . ISSN: 1907-2791Vol.5 No.2 Jul-Des 2010 pp.215-226

Purwanto,B.2015.Resep Herbal Tradisional. Yogyakarta: Madya pustaka
Putriningrum,dkk. Pengaruh Pengetahuan Dan Hypnobreastfeeding Pada Ibu Hamil Trimester III Terhadap Proses Menyusui. STIKes Kusuma Husada : Surakarta. 2014

Rajin M,dkk. Panduan Babon Akupuntur. Yogyakarta.Indoliterasi Grop. 2015

Riskesdas.Kesehatan lbu \& Anak. Ed.1.Vol.1. Jakarta.Balai Pustaka. 2010

Sulistyawati,dkk.. Efect Of Moringa Oleifera On Level Of Prolactin And Breast Milk Production In Postpartum Mothers. Belitung Nursing Journal.ISSN 2017247 4073. Volume 3, Issue 2, March-April 2017 